\title{
Transient skin and fur color change after trichotomy of the sacrococcygeal region for epidural anesthesia in a domestic cat (Felis catus)
}

\author{
Mudança transitória da cor da pele e pelo após tricotomia da região \\ sacrococcígea para anestesia epidural em gata doméstica (Felis catus)
}

\author{
Amândio José Soares Dourado'; Ignacio Sández Cordero²; Anabela Filipa Rodrigues Gomes ${ }^{1,3}$; \\ Luís Pedro Rodrigues de Lima Lobo ${ }^{1,4,5}$; Maria Isabel Ribeiro Dias ${ }^{3,6}$ (D) \\ Hospital Veterinário do Porto, Porto, Portugal \\ ${ }^{2}$ Serviço de Anestesia Móvel, Sinergia Veterinária, Galapagar, Madrid, Espanha \\ ${ }^{3}$ Universidade de Trás-os-Montes e Alto Douro, Escola das Ciências Agrárias e Veterinárias, Departamento de Ciências Veterinárias, Vila \\ Real, Portugal \\ ${ }^{4}$ Universidade do Porto, Centro de Estudos de Ciência Animal, Porto, Portugal \\ ${ }^{5}$ Universidade Lusófona de Humanidades e Tecnologia, Faculdade de Medicina Veterinária, Lisboa, Portugal \\ ${ }^{6}$ Universidade de Trás-os-Montes e Alto Douro, Centro de Pesquisa em Ciência Animal e Veterinária, Vila Real, Portugal
}

\begin{abstract}
A clinical case in which skin and hair color change occurred after sacrococcygeal epidural anesthesia in a nine-month-old Siamese cross queen undergoing ovariohysterectomy (OHE) is described. Six weeks after surgery, during a re-check, it was noted that in the sacrococcygeal region the color of the skin and new hair growth was dark with a color comparable to the color present on the body extremities (muzzle, pinnae, legs, and tail). The skin and new hair growth of the shaved abdomen presented a standard color. The key enzyme of the melanogenic pathway in mammals is tyrosinase (TYR), and the Siamese temperature-sensitive phenotype is the result of genetic mutations that makes TYR function thermolabile. The activity of TYR in these cats is limited to the extremities where the temperature is lower while pigment production is impaired in the other body areas. The trichotomy of the sacrococcygeal region performed during wintertime in an outdoor cat was probably the trigger for increased activity of TYR in this area promoting pigment production. The absence of the same alterations in the abdominal area may be justified by less exposure of that region to the external environment, as well as to the feline habits of sedentarism, that avoid significant cooling in these regions. This report highlights the importance of taking this type of occurrence into account when performing an epidural in the Siamese cat breed. Also, to avoid skin color change in this breed, the authors recommend a midline abdominal instead of a flank approach to perform OHE.
\end{abstract}

Keywords: Sacrococcygeal epidural anesthesia. Siamese cat. Skin and fur color change. Tyrosinase.

\section{RESUMO}

Descreve-se um caso clínico no qual ocorreu mudança na cor da pele e do pelo após anestesia epidural sacrococcígea numa gata cruzada de raça Siamês de nove meses submetida à ovariohisterectomia $(\mathrm{OVH})$. Seis semanas após a cirurgia, durante uma avaliação pós-operatória, notou-se que na região sacrococcígea, a cor da pele e o crescimento do pelo apresentavam uma cor escura, comparável à das extremidades do corpo (face, orelhas, membros e cauda). A pele e o crescimento do pelo do abdómen, que também havia sido tosquiado, apresentavam uma cor padrão. A enzima chave da via melanogênica em mamíferos é a tirosinase (TYR) e o fenótipo siamês sensível à temperatura é o resultado de mutações genéticas que tornam a função TYR termolábil. A atividade da TYR nestes gatos é limitada às extremidades onde a temperatura é mais baixa, enquanto a produção de pigmento é prejudicada em outras áreas do corpo. A tricotomia da região sacrococcígea realizada durante o inverno nesta gata com acesso livre ao ambiente externo, provavelmente determinou um aumento da atividade da TYR nesta área, promovendo a produção de pigmento. A ausência das mesmas alterações na região abdominal pode ser justificada pela menor exposição desta área do corpo ao ambiente externo, também devido aos hábitos felinos de sedentarismo, que evitam resfriamento significativo nestas regiões. Este relato destaca a importância de se levar em consideração a possibilidade deste tipo de ocorrência quando da realização de uma anestesia epidural nesta raça de gatos. Além disso, os autores recomendam uma abordagem abdominal na linha média ao invés de uma abordagem de flanco para realizar a OVH nesta raça, a fim de evitar a alteração da cor da pele. Palavras-chave: Anestesia epidural sacrococcígea. Gato siamês. Alteração da cor da pele e pelo. Tirosinase. 


\section{Correspondence to:}

Maria Isabel Ribeiro Dias

Universidade de Trás-os-Montes e Alto Douro, Escola das Ciências Agrárias e Veterinárias, Departamento de Ciências Veterinárias

Quinta de Prados

5000-801, Vila Real, Portugal

e-mail: idias@utad.pt

Received: December 27, 2020

Approved: June 2, 2021
How to cite: Dourado AJS, Cordero IS, Gomes AFR, Lobo LPRL, Dias MIR. Transient skin and fur color change after trichotomy of the sacrococcygeal region for epidural anesthesia in a domestic cat (Felis catus). Braz J Vet Res Anim Sci. 2021;58:e180388. https://doi.org/10.11606/ issn.1678-4456.bjvras.2021.180388

The known adverse cutaneous effects associated with epidural administration of opioids with or without local anesthetics are delayed hair growth, inflammatory skin reaction, and pruritus (Garcia-Pereira, 2018; Threlfall et al., 2012). The authors describe a clinical case in a Siamese cat in which a selective change in skin and hair color occurred after trichotomy of the sacrococcygeal region, with uneventful changes after the abdomen trichotomy. To the best of the authors' knowledge, this is the first report that describes a skin and fur color change from a clinical perspective after epidural anesthesia.

A nine-month-old Siamese cross queen weighing 2.7 $\mathrm{kg}$ and living in an outdoor environment was admitted to a veterinary hospital. The animal received sacrococcygeal epidural anesthesia in the context of a larger clinical study for the evaluation of the antinociceptive effect and stress-response of sacrococcygeal epidural anesthesia with morphine and lidocaine in cats undergoing ovariohysterectomy (OHE).

The patient was premedicated with dexmedetomidine $\left(0.01 \mathrm{mg} / \mathrm{kg}\right.$; Dexdomitor ${ }^{\oplus}$, Pfizer, Portugal $)$ and methadone $\left(0.2 \mathrm{mg} / \mathrm{kg}\right.$; Semfortan ${ }^{\circledR}$, Dechra, Portugal) into the epaxial lumbar musculature. Once an adequate level of sedation was achieved, a cephalic vein was catheterized using an aseptic technique and an infusion of Ringer's solution $(3 \mathrm{~mL} / \mathrm{kg} / \mathrm{h}$; Ringer lactate, Labesfal, Portugal) was administered with an infusion pump while the animal was pre-oxygenated via a face mask, using a flow rate of $3 \mathrm{~L} / \mathrm{min}$. General anesthesia was induced with alfaxalone ( $1 \mathrm{mg} / \mathrm{kg}$ IV; Alfaxan ${ }^{\oplus}$, Dechra, Portugal), administered for $60 \mathrm{sec}$, and repeated for adequate intubation with an appropriate endotracheal tube. The larynx was desensitized $30 \mathrm{sec}$ before intubating, with local application of $0.1 \mathrm{~mL}$ of $2 \%$ lidocaine (Lidocaine 2\%; BBraun, Portugal). The cuff was inflated until no leaks around the tube were detected during positive pressure ventilation with a pediatric Ayre's T-piece, Mapleson D modification. After general anesthesia induction, the bladder was manually compressed, the eyes were lubricated and robenacoxib (2 $\mathrm{mg} / \mathrm{kg}$ SC; Onsior ${ }^{\oplus}$, Elanco, Portugal) was administered. Anesthesia was maintained with sevoflurane (1.5\%; SevoFlo, Ecuphar, Portugal) delivered with the minimum oxygen rate $(\mathrm{mL} / \mathrm{min})$ required to maintain inspired end-expiratory carbon dioxide partial pressure equal to zero, with the cat ventilating spontaneously.

The cat was placed in sternal recumbency with pelvic limbs abducted. The sacrococcygeal region was clipped and aseptically prepared with $2 \%$ chlorhexidine followed by a $70 \%$ alcohol solution. The intervertebral space between the last sacral vertebra $\left(\mathrm{S}_{3}\right)$ and the first coccygeal vertebra $\left(\mathrm{Cd}_{1}\right)$ was located through the identification of anatomical bone references and, with the help of an assistant, applying movement of the first caudal vertebra, as described by O'Hearn \& Wright (2011). The epidural location was confirmed using a neurostimulator (NS) (Stimuplex HNS 12; BBraun, Portugal). After setting the NS to a fixed electrical current of $0.7 \mathrm{~mA}$, frequency of $2 \mathrm{~Hz}$, and pulse width of $0.1 \mathrm{~ms}$, a short bevel $\left(30^{\circ}\right) 22$ $\mathrm{G}$ and $50 \mathrm{~mm}$ long unipolar insulated needle connected to the NS was introduced in the sacrococcygeal space, as described by Otero et al. (2015). Needle advancement was stopped as soon as the tail movement was detected. Before needle withdrawal, the NS was turned off. Provided that no blood was aspirated or resistance to injection detected, a calculated volume was injected in the epidural space for $40 \mathrm{sec}$, consisting of a combination of lidocaine $(0.3 \mathrm{~mL} /$ $\mathrm{kg}$ ) and morphine (0.1 mg/kg; Morfina; BBraun, Portugal). Anesthesia was uneventful, and the cat was discharged after $8 \mathrm{~h}$ with a prescription of robenacoxib ( $2 \mathrm{mg} / \mathrm{kg}$ orally) for the following 5 days.

A week later, during a control postoperative visit, the suture presented good healing, and no abnormalities were detected on general physical examination. Six weeks later during a clinical reassessment on another routine visit for deworming, the owners reported that the skin and hair of the shaved area were darker. On physical examination a color change of the skin and new hair growth in the sacrococcygeal region was noted, with the color being dark as the color present on the body extremities (muzzle, ears, feet, and tail). No other skin changes were detected (Figure 1). The skin itself did not show any changes other than the change in pigmentation, such as erythema, flaking, or alopecia. The trichoscopic examination was not performed because there was no alopecic disorder. Melanotrichia can occur in acromelanism but also as a result of inflammatory 


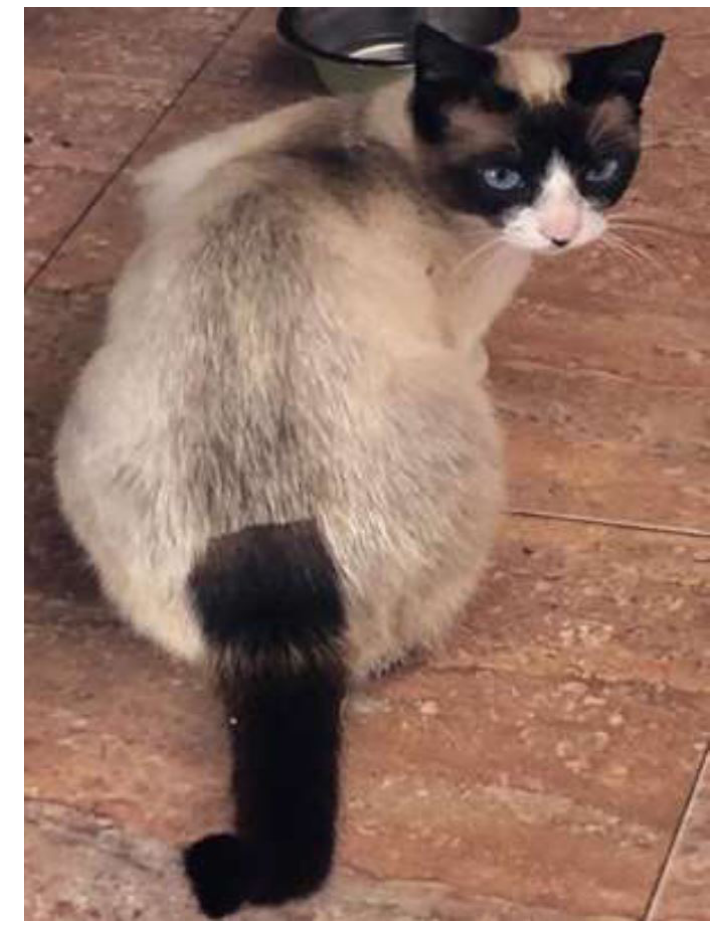

Figure 1 - Fur color change of sacrococcygeal region, 6 weeks after sacrococcygeal epidural anesthesia administration.

skin changes (pyoderma, panniculitis, vaccine reactions, traumatic injuries). In the dog, it is described as occurring after treatment of endocrinopathies (Miller et al., 2013a). In this sense, the trichoscopic examination was considered of little diagnostic value for the case in question. The skin and new hair growth of the shaved abdomen did not present any abnormalities. Six months later the skin color of the sacrococcygeal region returned to its normal appearance.

The cause of the color change reported in this Siamese cat was presumably related to its characteristic temperaturesensitive partial albinism phenotype, also known as "pointed" or "Himalayan color", where the fur is pigmented only at the extremities (Lyons et al., 2005). This phenomenon "feline acromelanism", is linked to the fact that Siamese, Himalayan, Balinese, Burmese, and Singapura breed cats have temperature-sensitive hair bulb tyrosinase (TYR) that is inactivated at temperatures of $35^{\circ} \mathrm{C}$ to $37^{\circ} \mathrm{C}$ (King et al., 1991; Miller et al., 2013b). The key enzyme of the melanogenic pathway in mammals is TYR (Barsh, 1996). The Siamese cat temperature-sensitive phenotype is the result of a mutation in which TYR became thermosensitive - an exon $2 \mathrm{G}>\mathrm{A}$ transition changing glycine to arginine (G302R) - in the cysteine-rich domain of feline TYR gene (Lyons et al., 2005). The precise mechanism for the loss of tyrosinase enzyme activity due to this mutation is unknown (King et al., 1991; Niesman, 2020). This mutation produces pigmentation only at the cooler extremities of the body and the warmer parts become progressively lighter, due to the impairment of the enzymatic activity by temperature (Lyons et al., 2005; Schmidt-
Küntzel et al., 2005). Therefore, if the skin is cooled enough, such as normally on the extremities (pinnae, tail, legs) or in other areas following shaving, pigment production may occur in the hairs, although the coat color changes are usually temporary. The trichotomy of the sacrococcygeal region was probably the trigger for the appearance of these alterations. The procedure promoted an increase of TYR activity in this area due to cooling of the skin. The procedure was performed in winter, with atmospheric temperatures in the geographic region where this outdoor cat lived around $7.6^{\circ} \mathrm{C}$.

The absence of alterations of the shaved areas in the abdomen may be justified by the fact that these are protected and less exposed areas and, also, due to the feline habits of sedentarism (several hours of sleep), thus avoiding significant cooling in these regions. This can also be explained by the findings of Iljin \& Iljin (1930) in a historical demonstration in which they concluded that the differences of temperaturecolor changes in the fur of Siamese cats were not only deeply influenced by external temperature but also by physiological factors determined by heat production and heat loss. They also concluded that different areas of the body have different thermal sensitivity thresholds.

Despite the reversible nature of the observed changes, this report highlights the importance of taking this type of occurrence into account when performing epidural anesthesia in this cat breed. Furthermore, to avoid skin color change in this breed, the authors recommend a midline abdominal instead of a flank approach to perform OHE.

\section{Conflict of Interest}

The authors declare no conflict of interest.

\section{Ethics Statement}

This clinical study was performed after obtaining the owners' informed written consent. It was authorized by the Ethics Committee of the University of Trás-os-Montes and Alto Douro (protocol no. 381-e-HV-2018).

\section{Acknowledgments}

This research was funded by National Funds by FCT Portuguese Foundation for Science and Technology, under the project UIDB/CVT/00772/2020. The authors thank Prof. Dr. José Ignacio Redondo from the Department of Medicine and Animal Surgery of the CEU Cardenal Herrera University, Valencia, Spain, for encouragement and Dr. Diana Ferreira, Dip. ECVD, for her support and advice in writing this manuscript.

\section{References}


Barsh GS. The genetics of pigmentation: from fancy genes to complex traits. Trends Genet. 1996;12(8):299-305. https:// doi.org/10.1016/0168-9525(96)10031-7. PMid:8783939.

Garcia-Pereira F. Epidural anesthesia and analgesia in small animal practice: an update. Vet J. 2018;242:24-32. https:// doi.org/10.1016/j.tvjl.2018.09.007. PMid:30503540.

Iljin NA, Iljin VN. Temperature affects on the color of Siamese cats. J Hered. 1930;21(7):308-18. https://doi. org/10.1093/oxfordjournals.jhered.a103354.

King RA, Townsend D, Oetting W, Summers CG, Olds DP, White JG, Spritz RA. Temperature-sensitive tyrosinase associated with peripheral pigmentation in oculocutaneous albinism. J Clin Invest. 1991;87(3):1046-53. http://dx.doi. org/10.1172/JCI115064. PMid:1900307.

Lyons LA, Imes DL, Rah HC, Grahn RA. Tyrosinase mutations associated with Siamese and Burmese patterns in the domestic cat (Felis catus). Anim Genet. 2005;36(2):11926. http://doi.org/10.1172/JCI115064. PMid:15771720.

Miller WH, Griffin CE, Campbell KL. Muller and Kirk's small animal dermatology. 7th ed. Missouri: Elsevier/ Mosby; 2013a. Endocrine and metabolic diseases; p. 501-53.

Miller WH, Griffin CE, Campbell KL. Muller and Kirk's small animal dermatology. 7th ed. Missouri: Elsevier/Mosby; 2013b. Pigmentation abnormalities; p. 618-29.
Niesman IR. Siamese cat tyrosinase has enhanced proteasome degradation and increased cellular aggregation. BioRxiv. 2020. http://dx.doi.org/10.1101/2020.06.03.132613.

O'Hearn AK, Wright BD. Coccygeal epidural with local anesthetic for catheterization and pain management in the treatment of feline urethral obstruction. J Vet Emerg Crit Care. 2011;21(1):50-2. https://doi.org/10.1111/j.14764431.2010.00609.x. PMid:21288294.

Otero PE, Verdier N, Zaccagnini AS, Fuensalida SE, Tarragona L, Portela DA. The use of a nerve stimulation test to confirm sacrococcygeal epidural needle placement in cats. Vet Anaesth Analg. 2015;42(1):115-8. https://doi. org/10.1111/vaa.12173. PMid:24815095.

Schmidt-Küntzel A, Eizirik E, O’Brien SJ, Menotti-Raymond $M$. Tyrosinase and tyrosinase related protein I alleles specify domestic cat coat color phenotypes of the albino and brown loci. J Hered. 2005;96(4):289-301. https://doi.org/10.1093/ jhered/esi066. PMid:15858157.

Threlfall A, Viscasillas J, Volk A. Localised cutaneous reaction after epidural administration of preservative-free morphine and ropivacaine?. Vet Anaesth Analg. 2012;39(5):55960. http://doi.org/10.1111/j.1467-2995.2012.00748.x. PMid:22789060.

Financial Support: This research was funded by National Funds by FCT - Portuguese Foundation for Science and Technology, under the project UIDB/CVT/00772/2020. 